\title{
外科的矯正治療における難易性の判断を考察する \\ Exploring the difficulty of surgical orthodontic treatment
}

高 橋 哲

Tetsu Takahashi

東北大学大学院歯学研究科 顎顔面 - 口腔外科学分野 Division of Oral and Maxillofacial Surgery, Department of Oral Medicine, and Surgery, Tohoku University Graduate School of Dentistry

田中 栄二

Eiji Tanaka

徳島大学大学院医歯薬学研究部 口腔頡顔面矯正学分野

Department of Orthodontics and Dentofacial Orthopedics, Institute of Biomedical Sciences,

Tokushima University Graduate School

\section{企画趣旨}

顎変形症は上下顎骨を含む顎顔面骨格の形態や大きさの異常，相対的位置の不調和によって不正咬 合と顔面の変形などの症状を示すものであり, 通常の歯科矯正治療では改善が困難な場合, 外科的矯 正治療の適応となります。さらに，顎骨の変形度，不正咬合の程度などにより，その治療難易度には 大きな違いがあり，治療方針の立案や術後安定性にも影響します。しかし，顎変形症の治療難易度に ついては，未だ統一した基準はなく，矯正歯科医と口腔外科医との間でも治療難易度に対する考え方 に差異があるものと思われます。

一方，顎変形症に対する外科的矯正治療では，矯正歯科と口腔外科との連携がポイントであり，両 診療科が症例検討会などを通して，症例分析によって得られた情報を共有し，相互の専門性を活用し た医療連携がきわめて重要です。

本シンポジウムでは, 外科的矯正治療の診療経験の豊富な 2 名の口腔外科医と 2 名の矯正歯科医に, 顎変形症に対する外科的矯正治療の治療難易度について, 日頃実施している難易度判定や難症例に対 する対処法などをお話していただきます。治療難易度をどのようにとらえるかということだけではな く，どのようにしたら難易度を低くすることができるのか，難易度の低下が術後安定性の向上にどの ように関わっているのかなどにも言及していただきたいと思います。

今回のシンポジウムが，矯正歯科医と口腔外科医の “術後安定性と治療難易度を踏まえた治療ゴー ルの共有”につながる，有意義なものとなることを祈念します。

\section{講演者}

大阪大学 相川 友直

タイトル：外科的矯正治療における治療難易度を考える；術後安定性と手術難易度を踏まえた治療 ゴールの共有

東北大学 山内 健介

タイトル：三次元画像から読み解く難易性の判断

一術中・術後のリスクマネージメントから考慮した治療計画—

日本大学 田村 隆彦

タイトル：術後後戻りを考察する一呼吸機能の観点からの推察—

東京医科歯科大学 東堀 紀尚

タイトル：骨格性下顎前突症に対する外科的矯正治療の難易度を矯正歯科医の視点から考察する 


\section{外科的矯正治療における治療難易度を考える;術後安定 性と手術難易度を踏まえた治療ゴールの共有 \\ Considering the difficulty in surgical orthodontic treatment; sharing of treatment goals based on postoperative stability and difficulty of surgery}

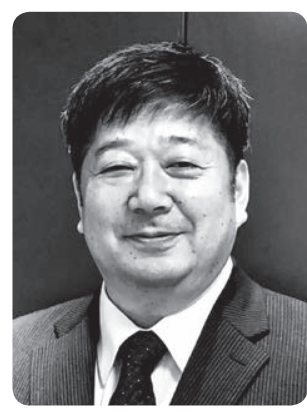

相川 友直

Tomonao Aikawa

大阪大学大学院歯学研究科 口胫外科学第一教室

The $1^{\text {st }}$ Department of Oral and Maxillofacial Surgery, Osaka University Graduate School of Dentistry

顎矯正手術自体の難易度は顎骨形態, 上下顎骨の位置関係, 軟組織の状態や位置関係, 神経筋制御, 勒帯や筋付着, 顎関節疾患, 顎骨の移動様相など様々な因子が関与する。経験豊富な術者や矯正歯科 医は直感的に判断できる部分も多い。一方，術後安定性に関しては術後数か月を経過して出現する予 期せぬ後戻りは難症例であったもしくは不適切な治療設計であったとも言える。

顎矯正手術の術後安定性に関する最近の systemic review は主に欧米での臨床結果をもとにした研 究であるものの, 多くの示唆を与えるものである。その反面, われわれが経験する本邦の治療予後と は異なるものもあり，その代表例は上下顎複合体の反時計方向の移動であろう。欧米では上下顎複合 体の反時計方向の回転移動（CCWR）が計画されることが多く，その安定性は変形性顎関節症や関節 円板の転位がない顎関節の状態が良い状態では高い安定性が報告されており，また強固な骨接合が要 求される。一方，われわれを含め本邦では上下顎複合体の CCWRによる術後の下顎頭吸収による後戻 りや，咬合は維持されているものの下顎頭体積が減少することも多く, CCWR はいまだにチャレンジ ングな術式でこれを避ける傾向にある。実際，われわれの経験した予後不良症例は Class II 症例と偏 位症例偏位側の下顎頭の変化に起因するもののみであった。

外科的矯正治療の目的は安定した咬合と顎位の獲得のみならず，整容面，上気道スペースや顎関節 の状態に配慮した治療が求められている。特にClass II では整容面と上気道腔の拡大を第一義にすると CCWR が有効であることは言うまでもなく，安定性を第一義にすると下顎枝高径を維持する範囲での CCWR で整容面の改善はオトガイ形成術の追加で対応することになろう。しかし，顎骨移動方向は術 前矯正終了時の上顎前歯の歯軸, 露出量などにも左右されるため, 元来もくろんだ顎骨移動をし難い など，外科医と矯正歯科医との治療ゴールの共有の重要性を感じる。そこでわれわれの施設では CT, 顎関節 MRI を始め臨床検査結果をもとに治療計画と治療ゴールを共有すべく医療連携を深める取り組 みを行ってきた。個々の顎変形症病態に対して多様な治療計画が考えられるが，本発表では当科での 術後不良症例の提示と顎関節状態, 移動様式等の関連, そして安定性が低い＝難易度の高い症例に対 する口腔外科と矯正歯科との連携の現状と対策を示させていただく。 


\section{略 歴}

1990 年 3 月 広島大学歯学部 卒業

1994 年 3 月 大阪大学大学院歯学研究科 修了（口腔外科学第一）

1994 年 4 月〜 1997 年 3 月

日本学術振興会 特別研究員 (口腔外科学第一)

1997 年 4 月〜 1998 年 2 月

大阪大学歯学部附属病院 口腔外科 1（制御系）医員

1998 年 2 月〜 1999 年 4 月

八尾徳洲会総合病院 歯科口腔外科 医長

1999 年 4 月～ 2001 年 3 月

米国マサチューセッツ総合病院 内分泌部門 研究員

2001 年 4 月～ 2003 年 3 月

大阪大学歯学部附属病院 口腔外科 1 (制御系) 医員

2003 年 3 月 2009 年 10 月

大阪大学大学院歯学研究科 口腔外科学第一教室 助教

2009 年 11 月～大阪大学歯学部附属病院 口腔外科 1 (制御系) 講師

2019 年 9 月～大阪大学大学院歯学研究科 口腔外科学第一教室 准教授

\section{資 格}

日本口腔外科学会 専門医 - 指導医

日本がん治療認定医機構 がん治療専門医（歯科口腔外科）

日本口腔科学会 認定医 


\section{三次元画像から読み解く難易性の判断}

一術中・術後のリスクマネージメントから考慮した治療計画一

Evaluation of the difficulty of surgical orthodontic

treatment from preoperative 3D CT images

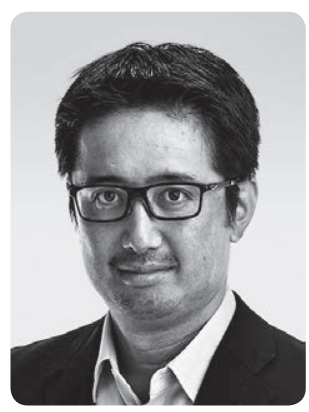

山内 健介

Kensuke Yamauchi

東北大学大学院歯学研究科 顎顔面 · 口腔外科学分野

Tohoku University Postgraduate School of Dentistry, Division of Oral \& Maxillofacial Surgery

顎変形症治療での口腔外科側の難易度の判断としては, 全身的背景と局所的（骨格的）背景に分け ることができ，全身的な問題に対しては麻酔医との診断・評価の下で管理されるべきものが多い。一 方，局所的な顎顔面形態による難易度の判断としては，術前の治療計画で考慮すべきものと術中に対 応すべきものに分けられる。前者は一般的に大きな移動量を伴う症例や顎関節に何らかの異常を示す 症例などであり，後者は骨形態の特異的異常や骨片干涉への対応などが挙げられる。

CT 画像の応用によって, 解剖学的構造の把握がより確実になり, 下顎管の走行, 下顎孔の位置, 上 顎最後方臼歯から翼突上顎縫合部の形態などの把握は有用であると共に, 顎骨内の質的評価もできる ことから術前評価としての正確性は向上し，合併症予防に寄与しているものと考えられる。また，顔 面非対称症例では, 従来の頭部 X 線規格写真のみでの評価と比較し, CT 画像による 3 次元画像の応 用によって術後硬組織レベルでの対称性の把握は正確にでき, 術後遠位骨片の位置予測は容易となっ た。この事前予測により, 術後オトガイ部の偏位の有無, 近位/ 遠位骨片の干渉の有無・程度が術前 から把握できることにより, 顔面非対称症例での難易度判断も比較的正確に行うことが可能である。 この術前予測から考えられる問題としては, 顔面非対称の予期せ好発生または残存, 下顎骨片干涉に よる術式変更および付帯手術の検討が挙げられる。

このように応用が進んでいる $3 \mathrm{D}$ 画像ではあるが, 臨床的に有用なのは硬組織のみであり, 軟組織に 関しては再現性に課題を有しているのが現状である。特に軟組織・硬組織の基準に差違があるもので は，最終的には顔貌形態である軟組織に合わせるような症例もあり，CT による $3 \mathrm{D}$ シミュレーション で全て解決できるとは限らない。本シンポジウムでは, これらの画像情報から得られる難易度判断に ついて解説するとともに, 現状での課題を供覧することで予知性と安全性の高い顎変形症治療の展開 について検討していきたい。 


\section{略 歴}

2001 年 3 月 東北大学歯学部 卒業

2001 年 4 月 九州歯科大学 口腔外科学第二講座 研究生

2001 年 11 月 香川県立中央病院 歯科口腔外科 嘱託医

2003 年 4 月 九州歯科大学 口腔外科学第二講座 助手

2007 年 4 月 九州歯科大学 形態機能再建学分野 助教

2011 年 4 月 オランダ・マーストリヒト大学 頭蓋顎顔面口腔外科講座 留学（～2012 年 3 月)

2012 年 9 月 東北大学大学院歯学研究科 顎顔面・口腔外科学分野 助教

2013 年 4 月 東北大学大学院歯学研究科 顎顔面・ 口腔外科学分野 講師

東北大学病院 歯科インプラントセンター 副センター長（兼任）

2017 年 3 月 東北大学大学院歯学研究科 顎顔面・ 口腔外科学分野 准教授

現在に至る

\section{資 格}

歯学博士, (公社) 日本口腔外科学会専門医・指導医, (公社) 日本口腔インプラント学会専門医・指 導医，がん治療認定医（歯科口腔外科），臨床研修指導歯科医師 


\section{術後後戻りを考察する}

一呼吸機能の観点からの推察—

Consideration of relapse after orthognathic surgery

-Inference from the viewpoint of respiratory function-

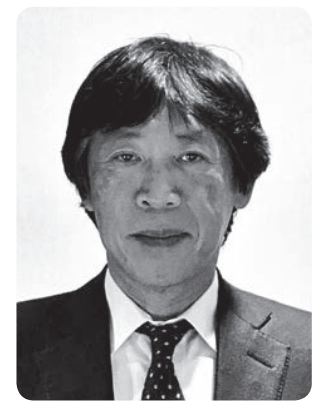

田村 隆彦

Takahiko Tamura

日本大学歯学部 歯科矯正学教室

Nihon University School of Dentistry, Department of Orthodontics

外科矯正の難易度は，われわれ矯正歯科医からすると手術をしても顔貌の良好な改善が得られな かったり，術前の模型上での咬頭嵌合位は良好でも，術後被蓋関係に問題が生じる後戻りを起こした り，顎関節に異常が生じたり等々あります。しかし，これらを術前より予測判断することは容易ではな いでしょう。しかし，一つの要因として機能に関することは考えられ，ヒトが生きていくうえで必須な 呼吸から考えてみたいと思います。

ヒトがこの世に生を受け，生まれてくるときに初めて行うことは呼吸であり，呼吸には大きな意味が あると思われます。乳児は 1 歳まではほとんど口では呼吸をしないとされていますが，日本人は口呼吸 の割合が高く，それは離乳の時期が 1 歳前後と欧米（3-4歳）に比べて早く, 鼻呼吸が定着する前に口 呼吸を覚えてしまうため, といわれています。それ以外にも鼻の空気の通り道が狭い，鼻の穴が小さ い, アデノイドや口蓋扁桃腺が大きい, 上顎の発達が悪い, などの人はなりやすいといわれています。 また，上記のような特徵がない人でも幼児期に口呼吸の癖をつけてしまうと，そのまま常習化すること にもなります。口呼吸になると舌位も変化しなければ呼吸に対応できず，低位舌になります。

さらに，口呼吸では猫背になり下顎を後下方へさげ，頭を後方へ傾斜させるので，顔の形がアデノ イド様顔貌といわれる面長であご幅が狭い顔つきに変わってしまい, 口輪筋や煩筋の緊張感がないた めに，骨格的な歯列不正になることは周知の事実です。

口呼吸で低位舌という機能が不正咬合を造りだしていくということは，悪い機能を改善しなければ 後戻りが起きるのは必然であり，簡単な症例の手術を施行して骨格的な改善はできたとしても機能が 改善しなければ，後戻りに繋がる症例は少なくないと思います。

術後の後戻りは治療期間を長期化させ，最終の咬頭嵌合位を妥協せざるを得ないことにも繋がると 思います。

矯正歯科医が外科矯正手術の難易度を下げるための唯一の方法は, 術前の模型上での咬頭嵌合位を 最終アイデアルに近づけ，手術に臨めるようにすることと口呼吸を鼻呼吸に変えて舌位を正しい位置 にすることであると私は考えます。

顎顔面頭蓋の不調和は手術による上下顎骨の位置を改善することで成し遂げられるところが大きく， 下顎前突症であれば下顎の $10 \mathrm{~mm}$ 以上の後方移動は睡眠時無呼吸症候群への潜在人数を増加させるこ とになり，上顎骨への前方移動を余儀なくさせられます。また，下顎後退症であれば下顎を前方移動 しなければならず，術後に進行性下顎頭吸収（PCR）について考慮しなければならなくなります。特 にPCR については咬頭嵌合位をしっかり確立し，骨格を作り上げてきた筋肉が術後の骨格に適応する まで咬頭嵌合位と顎運動を保持し，口呼吸の改善によって良好な舌位を回復させることで，下顎頭へ の負担が多少なりとも軽減できるのではないかと考えます。 


\section{略 歴}

1986 年 3 月 日本大学歯学部 大学院歯学研究科 卒業

1986 年 5 月 日本大学歯学部 助手

1987 年 4 月 日本大学 助手

2004 年 4 月 日本大学 講師 (専任扱)

2007 年 4 月 日本大学 専任講師

2009 年 4 月 日本大学歯学部 診療 准教授

2019 年 4 月 日本大学歯学部 診療 教授

現在に至る

\section{所属学会および学会活動歴}

1982 年 9 月 日本矯正歯科学会 会員

1982 年 9 月 東京矯正歯科学会 会員

1990 年 8 月 日本矯正歯科学会 認定医 (登録番号第 608 号)

1991 年 7 月 日本顎変形症学会

2003 年 8 月 日本矯正歯科学会 指導医 (登録番号第 559 号)

2003 年 7 月 日本顎関節学会 会員

2007 年 4 月 日本矯正歯科学会 代議員

2008 年 12 月 日本矯正歯科学会 専門医 (登録番号第 233 号)

2014 年 4 月 日本矯正歯科学会 専門医委員会委員

現在に至る

\section{受賞歴}

2014 年 6 月 日本顎変形症学会 学会賞 


\section{骨格性下顎前突症に対する外科的矯正治療の難易度を矯 正歯科医の視点から考察する \\ Consideration of the difficulty of surgical orthodontic treatment for skeletal mandibular prognathism from the perspective of orthodontists}

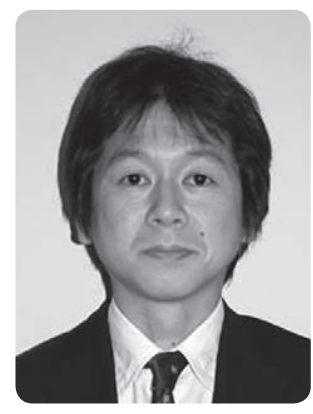

東堀 紀尚

Norihisa Higashihori

東京医科歯科大学大学院医歯学総合研究科 顎顔面矯正学分野

Department of Maxillofacial Orthognathics, Graduate School of Medical and Dental Sciences,

Tokyo Medical and Dental University

顎変形症患者は，咬合不全による咀嚼・発音障害といった機能的問題，顎骨の変形による顔貌の美 的不調和，加えてそれらが直接的・間接的に引き起こす心理社会的問題など様々な臨床的課題を抱え ており，その治療は困難を極めます。われわれは，これらの問題点を把握した上で，最善の治療法を 選択し，治療計画を立案しますが，咬合不全や顎骨の変形の程度，どのような治療目標や治療法を選 択したかによって，その治療の難易度は異なります。治療の難易度というものは，ある程度共通した 認識がある一方，術者によって難易度に対する考え方が異なる場合もあります。例えば，一般的に重 度の骨格性開咬や骨格性下顎偏位症例は，手術手技や安定性の観点から難症例と考えられております が，この両者の難易度に差はあるでしょうか。術者の経験や知識によって治療の難易度の考え方が異 なるため，様々な考えがあるのではないでしょうか。難易度を左右する因子としては，骨格性や歯性 要因, 個々の歯の状態や欠損歯の有無, 歯周組織, 年齢, 歯の移動様相, 手術術式等が挙げられ, こ れらの因子の組み合わせ，各因子の強度によっても難易度が異なると思われます。しかしながら現状 では，統一した難易度の基準が存在しておりません。

近年の顎矯正手術の技術的進歩に伴い，上下顎移動術をはじめとした多様な手術法が選択されるよ うになってきたことに加え，歯科矯正用アンカースクリューの保険適応により従来困難であった歯の移 動が可能となり, 治療方法の選択肢が増え, 様々な状況に対応が可能となり, 難症例にも良好な治療 結果を得ることが可能となってきました。一方，治療前は通常の顎変形症と思われたにも関わらず， 治療期間の長期化を認め, 咬合は改善しているものの, やや不十分な咬合状態で動的治療が終了した 症例も散見され，このような “隠れ難症例”に潜む，治療を困難にさせる要因の存在が示唆されます。 そこで，われわれは，動的治療が終了した骨格性下顎前突 100 症例に対し，動的治療終了時の咬合評 価としての PAR index 值と動的治療総回数を用いて難易度の指標の作成を試み，それを基に治療に苦 慮した症例を抽出し，それらの症例を詳細に検討することにより，治療の難易度を左右する要因を検 討しました。

本講演では，検討内容を報告するとともに「治療難易度を踏まえたゴールの共有」について私見を 述べさせて頂きたいと存じます。 


\section{略 歴}

2000 年 東京医科歯科大学歯学部 卒業

2004 年 東京医科歯科大学大学院医歯学総合研究科 顎顔面矯正学分野 博士課程修了

2005 年 東京医科歯科大学 疾患遺伝子実験センター 博士研究員

2006 年 東京医科歯科大学歯学部附属病院 矯正歯科外来 医員

2007 年 Life Sciences Institute, University of British Columbia 博士研究員

2010 年 東京医科歯科大学大学院医歯学総合研究科 顎顔面矯正学分野 助教

2019 年 東京医科歯科大学大学院医歯学総合研究科 顎顔面矯正学分野 講師

現在に至る 